\title{
WOMAN INTEGRATION IN THE MILITARY SERVICE. THE CASE OF BULGARIA
}

\author{
Militsa Ivanova KARADZHOVA-MANOVA \\ "Neofit Rilski”" South-West University, Blagoevgrad, Bulgaria \\ militsa.karadzhova@gmail.com
}

\begin{abstract}
According to most of the research papers there are good social psychological conditions, which influence the smooth integration of women into the military. Furthermore, the opinion of military men to women integration in it, is generally well accepted. Most of them except women as equal and treat them with respect. A considerable percentage of women in the army share that it is not necessary for them being privilege, compare to men. Additional studies suggest that higher ranking officials in the military, know well their subordinate's issues and it is not their gender that defines their capabilities, but their experience and qualities.
\end{abstract}

\section{Keywords: gender, UNSC Resolution 1325, Bulgarian army}

\section{Introduction}

Asking most people to visualize a soldier, they will for sure describe strong and masculine man with a rifle and a uniform, exactly this visualization the 21-century population is trying to change in people's mind. These days is not unusual to see a woman in fire-fighter or police- uniform, as well as a man can be employed as a stay-athome-dad or a nurse. Exactly such differences can trigger people's mind into thinking that both sexes have an equal role in the society. One of the most highly discussed topics in the last two decades is connected with gender discrimination. Being noble and having dignity as a human does not depend on being male or female, it depends on a number of other factors like being compassionate, being able to provide support wherever needed and help the new generations to grow up in a normal, loving and discrimination free environment. Nowadays gender discrimination is visible in most of the working environments in the world- going down from white-collar employees, all the way down to the blue- collar employees. The army is not an exception. Men and women in the military should be heavily involved in the problem with gender discrimination.

\section{UNSC Resolution 1325}

On 31 October 2000, the Security Council of the United Nations Organization adopted Resolution 1325 on Women, Peace and Security. Resolution 1325 is first of its kind. It is meant for those women who are directly affected from military conflicts, and also emphasises the significant role of women in the conflict of all aspects of achieving peace and peacekeeping. This document calls for respect for the contribution of women in the EU peace-building, especially in the decision-making processes.

Resolution 1325 is helping to understand how important is the role of woman in the avoidance of war conflicts, keeping the peace and helping people in need of humanitarian help. Also, it helps them to encourage and maintain peace and security globally. United Nations (UN) uses Resolution 1325 to increase the involvement 
of women and integrate gender perceptions. This Resolution will particularly be useful during war conflicts, because it can help to take actions and protect women from war violence, sexual abuse or rape. The implementation of Resolution 1325 in the Ministry of Defence in Republic of Bulgaria was advanced together alongside the "Women's Army Association". The task of this is to stimulate and upkeep the esteem and communal position of females in the Armen Forces and to guard their mutual benefits. Resolution 1325 was the original official and lawful article from the Security Council that required sides in an argument to prevent harms of women's rights, to help women's partaking in peace discussions and sessions.

Based on NATO's Commission on sex perceptions, in the past years, a little over $15 \%$ of total military students in Bulgaria's military educational institutes are women. With this fact Bulgaria is in the 7-th place with this high percentage of active duty woman military employees, after Hungary, Latvia, Slovenia, Greece, USA and France.

\section{3. "Opening" the army to the women}

The first female soldiers appeared in the Canadian army in 1986. In the Bulgarian military schools, the girls were accepted for the first time in 1988. The "opening" of the Bulgarian Army to female representatives is one of the essential elements of the military reform. As a result of what has been done in this respect, it can be said that in this country the military profession started losing its purely male character and women have more opportunities for professional realization in the armed forces. The successful professional realization of female military personnel is determined to a great extent by the material and social working conditions of the division. In this respect, relations between the two sexes are of great importance. About $85 \%$ of the army's staff members share the view that the military profession is suitable for women. According to half of the respondents, however, it is necessary to take into account the specifics of the soldier's service, which is why the women's staff should be assigned to positions corresponding to the peculiarities of their sex.

Despite the existing problems, the socio psychological climate in the army in Bulgaria is normal and in no case can we talk about forms of discrimination either on a sexual, ethnic or religious basis, both gender are agree with this. About threequarters of women say they feel relaxed and confident of themselves since they have been in the military service.

The specificity of the military service also requires the respective qualities of the servicemen for their successful professional realization. In both genders, importance is attached to the qualities of "discipline", "responsibility" and "teamwork skills". This is quite natural because the requirements of the service in the army are the same for all soldiers, and the character of the military activity implies the existence of these qualities. In addition to these, women's specific requirements like "loyalty" and "organizing" are most important, and for men - "courage" and "sacrifice". With regard to the motivation to choose the military profession there are no differences between the representatives of both sexes. Leading motives in this respect are: job security, military benefits, personal interest, and love for the military profession, opportunities for further qualification, existing unemployment, the possibility of taking part in peacekeeping missions, the public prestige of the military profession, family tradition, etc. The public prestige of the army and family tradition are a significant factor in choosing the military profession, especially for women in command positions.

\section{Maternity leave policy}

Additional respectable and worthy gender strategy in the Bulgarian Armed Forces can be determined as parental life, rights and privileges. Referring to the Labor Code, the leave, which is given for maternity is 410 days for each kid and the parent permission 
for leave is 52 weeks for the woman along with for the man and it is moveable and manageable between the mothers and fathers. Flexible working programs and parttime service are acceptable in case of parental leave or taking care of sick or old relatives. There have been made exceptional programs for supporting parents when they work for the armed forces or if they are divorced or single.

In the army as a whole, there is a good socio- psychological climate conductive to the successful professional realization of female servicemen. The attitude of male soldiers towards the female army is positive. Most of them accept them as equal in service and do not underestimate them. The overwhelming majority of women in the army have the opinion that there is no need to enjoy any special references. In the Bulgarian army there are prerequisites for the successful professional realization of the female military servicemen. As well as the fact that in a relatively short period of time they managed to conquer such an inaccessible territory as the profession of military servicemen. It is wrong to think that any woman who chooses to wear a uniform faces discrimination or neglect on the part of men in the army. Although from the outside it seems as if the gentle sex is leading a constant struggle to prove, Sergeant Parvanova refutes this bias. She says, "I have not felt the distinction between women and men in the title or attitude in the institution itself, but outside of it".

\section{Prevention of Sexual abuse}

Women in the military have been speaking out about sexual harassment and assault for decades. However, with time and the ratification of polices against discrimination this is rarely seen anymore. For 2015 in Bulgaria there is no single submitted complaint for sexual abuse in the army. This is mainly due to the policies to prevent sexual harassment and sexual abuse. They contain different plans and actions like public instruction and seminars with nongovernmental organizations and global meetings and debates in public. Gender topics, as well as the issues of sexual harassment are part of educational packages or units in military academies.

\section{Military Equipment}

Military equipment is adopted for both women and men. In 2015 no alterations were made to it and the facilities. The working environment is proper for both genders. There are commonly accepted standards and conditions for identical contact of men and women to all spheres of military life. Facilities are modified for both sexes and no difficulties regarding their use were reported by either men and women. Uniforms and combat uniforms are modified for both men and women as decided by Ministry of Defence. In preparation for missions and operations abroad, soldiers and civil servants receive gender training issues and related topics. The personnel of the aircraft, which participates in missions and operations under the flag of various international organizations takes responsibility for respect for and active implementation of the goals of women's participation and protection in the area of responsibility.

\section{Conclusion}

Can the scepticism and negative emotions be eliminated? Yes! In order to be equal partners of men in military service, the ladies with uniforms have to be harsh, side by side with their colleagues in the rolls. Also, in field training, drills and shooting practise, women have to prove themselves in order to accomplish good results in the tasks, given to them. Thus, to fight for their rightful place in the military service. The measures taken by the Ministry of Defence of the Republic of Bulgaria to remove the legitimate and organizational barriers to the implementation of the gender equality perspective and to create a good organizational climate in the military formations are delivering results. Women in uniform can live with dignity and expectation of career development and social support. Sometimes, problems with 
overcoming prejudices and stereotypes in people's minds can slow down the process, which requires targeted politics, system work and education.

\section{References}

[1] Summary of the National Reports of NATO member and partner nations to the NATO Committee on Gender Perspectives (NGGP), 2015;

[2] Action plan of implementation of United Nations Security Council Resolution 1325 at the Ministry of Defense,

[3] ЖЕНАТА В УНИФОРМА В БЪЛГАРСКАТА АРМИЯ - РЕАЛНОСТ И ПРЕДИЗВИКАТЕЛСТВА, Майор Даниела Благоева заместник-командир на под.42 000-Карлово. Accessed from: https://www.mod.bg/bg/EXT/wacp/documents/004.pdf

[4] Atanasova-Krasteva, N. (2017, June). Role of Women in Security and Defense: Bulgarian National Policies and Experience. In International conference KNOWLEDGE-BASED ORGANIZATION (Vol. 23, No. 1, pp. 9-14). De Gruyter Open.

[5] Bulgarian government report on implementation of Beijing platform for action (1995), adopted at the IV UN World Conference on Women and the outcome of the $23^{\text {rd }}$ special session of the general assembly (2000). (pp.1-19)

[6] Committee on Equality and Non-Discrimination, Women in the armed forces: promoting equality, putting an end to gender-based violence.

[7] Белова-Ганева, Габриела (2013). Актуални тенденции в защитата на правата на човека (pp. 15-58)

[8] Zh. Ualieva, South-West University "Neofit Rilski”, Blagoevgrad, Issues of realization of the general principles off accountability in national legal system of the Republic of Kazakhstan, Bulgaria, (pp. 38-42)

[9] Nikolay Marin, South-West University "Neofit Rilski", Blagoevgrad, Problems of systematic character in the execution of the mutual assistance clause under art. 42, para.7 of the treaty on European union (pp.46-55), (Vol.3,No 2, 2016) Papers of BAS, Humanities and Social Sciences

[10] Gabriela Belova, South-West University "Neofit Rilski", Nikolay Marin, South-West University "Neofit Rilski",Some issues related to the irregular or undocumented migrants, (pp.561-562), Kutafin University Law Review (Vol.4, Issue 2, 2017) 